\title{
Study on the Durability of Concrete under an Underwater Coupling Environment
}

\author{
Chunhua You $(\mathbb{D}$ and Gen He \\ School of Architecture Engineering and Art Design, Hunan Institute of Technology, Hengyang 421002, China \\ Correspondence should be addressed to Chunhua You; 2005001486@hnit.edu.cn
}

Received 4 July 2021; Accepted 9 August 2021; Published 13 September 2021

Academic Editor: Xudong Zhang

Copyright (C) 2021 Chunhua You and Gen He. This is an open access article distributed under the Creative Commons Attribution License, which permits unrestricted use, distribution, and reproduction in any medium, provided the original work is properly cited.

\begin{abstract}
The durability of the concrete structure under the coupling effect of underwater corrosion particles has always been one of the hot issues at home and abroad. Aiming at the damage problem of the underground concrete structure in a marine and offshore chloride corrosion environment, based on the pile foundation engineering of the Coastal Industrial Park, the corrosion resistance test of pile foundation concrete is carried out. By preparing 7 kinds of pile foundation concrete samples with different mix proportions, the mechanical properties of concrete with different ages were analyzed under the coupling environment of groundwater. The chloride penetration resistance of concrete was analyzed by the RCM method, and the sulfate corrosion resistance was analyzed by the 17D accelerated simulation test. The test results show that with the decrease of the water-cement ratio and the increase of the cementitious material, the concrete damage is less and the durability is improved. It is suggested that the water-cement ratio of 0.34 and the cementitious material of $480 \mathrm{~kg} / \mathrm{m}^{3}$ be selected for the preparation of the pile foundation concrete; when the content of fly ash is $15 \%$, the antisulfuric acid corrosion ability of the concrete cementitious system can be enhanced and the concrete with $40 \%$ mineral powder has strong antichloride ion corrosion ability; the results show that the chloride diffusion coefficient of concrete samples with seven mix proportions is less than $6^{*} 10-12 \mathrm{~m}^{2} / \mathrm{s}$, which can meet the durability design requirements and reduce the damage of concrete. The sulfate corrosion resistance of concrete samples with high-efficiency additives is the best.
\end{abstract}

\section{Introduction}

The loss caused by corrosion accounts for 3\% 5\% of GDP in China every year, and the direct loss caused by marine corrosion is up to 1 trillion yuan. However, there are a lot of corrosive ions such as $\mathrm{SO}_{4}{ }^{2-}, \mathrm{Cl}^{-}$, and $\mathrm{Mg}^{2+}$ in the soil and water near the sea in China. The existence of these ions seriously affects the durability of offshore pile foundation engineering and even threatens the safety of the superstructure [1-4]. Therefore, how to alleviate the corrosion damage of concrete caused by different types of salt and improve the sulfate and chloride corrosion resistance of pile foundation has become one of the important contents of the durability research of the offshore engineering structure. At present, many scholars use indoor tests to study the influence of various raw materials and the corrosive environment on the durability of concrete. Han [5] proposed an improved diffu- sion coefficient and, based on the finite element method program, estimated the chloride concentration according to the concrete depth and internal and external conditions, and compared the predicted chloride concentration with the experimental value. Zhang et al. [6] put forward the optimal mixing amount of body type preservative for sulfate resistance of concrete. The results show that the optimal mixing amount of body type preservative for sulfate resistance of concrete is $8 \%$. Chen et al. [7] studied the corrosion behavior of reinforced concrete in acid medium by means of an acidimeter, SEM (scanning electron microscopy), XRD (X-ray diffraction), EDS (energy-dispersive spectroscopy). The results show that $\mathrm{SO}_{4}{ }^{2-}$ and $\mathrm{Cl}^{-}$are easily adsorbed on the surface of reinforced concrete through the protective layer of concrete to destroy the passive film and cause corrosion of reinforced concrete. At the same time, it is found that cement concrete can delay the corrosion process of the 
corrosive medium. Ge et al. [8] studied the durability of concrete with different strength grades and air content in different concentrations of sulfate solution under alternate freezethaw and dry-wet cycles. The results show that the higher the concentration of the sodium sulfate is, the stronger the corrosion is, and the mass loss is the largest under freezethaw dry-wet cycles. Most of the existing studies analyze the influence of single or multiple concrete raw materials on the durability of concrete through laboratory tests, but there are few studies on the long-term corrosion resistance of cast-in-place piles in coastal sites.

A concrete pile foundation is an important structure of buildings, and its durability is very complex and affected by many factors. For example, neutralization of concrete, rust and corrosion of steel bars, and various other physical and chemical reactions will cause corrosion of concrete. Therefore, there are many factors that cause the durability change of concrete and the influencing factors in different environments are different, which makes the mechanism of the concrete corrosion process in different environments different. The concrete pile foundation around the sea and offshore is mainly due to steel corrosion, which affects its durability, while the pile foundation in saline alkali soil is mainly due to concrete structure damage [9]. Therefore, scholars at home and abroad have done a lot of relevant research on this issue and achieved certain results. At present, there are many researches on the durability of the above ground part of concrete buildings, but few researches on the durability of the underground pile foundation. This is because the corrosion and damage of the underground part will not be found, so we do not pay enough attention to it. However, compared with the above ground part, the underground part of the pile foundation is more likely to be damaged.

Reinforcement is an important component of the concrete pile foundation. The hydration product of cement in concrete is alkaline. The alkaline environment forms a passive film on the surface of the reinforcement. When corrosive $\mathrm{Cl}^{-}$in the marine environment contacts the surface of the reinforcement, its $\mathrm{pH}$ value will be reduced, thus damaging the passive film of the reinforcement and causing corrosion of the reinforcement [10]. The corrosion rate of the steel bar in the concrete pile foundation controls the durability of the concrete pile foundation to a certain extent. Many scholars have studied the relevant theoretical models of the corrosion rate of the steel bar in concrete. Because the corrosion of the steel bar is affected by many factors, the relevant models that can generally simulate the corrosion of the steel bar have not been established. Most of the existing empirical models are used to estimate the corrosion rate of the reinforcement and then judge the durability of the pile foundation. The product of the steel bar rust will increase the volume of the steel bar, which will cause the internal cracking of concrete. With the extension of time, the concrete and steel structure are constantly corroded, which will lead to cracking, falling off, and other problems, and finally, the concrete pile foundation is damaged. Sulfate corrosion of the concrete pile foundation in the Salt Lake area is also very obvious, and its corrosion mechanism is very complex, which can be divided into physical erosion and chemical erosion. The physical erosion part of the sulfate does not react with the components in the concrete, but through the salt crystallization. The expansion of the salt crystallization makes the concrete internal pressure, resulting in cracking [11]. The domestic theories of sulfate physical corrosion mainly include the volume change theory, crystallization water pressure theory, and salt crystallization pressure theory. These three theories are all due to the relevant reaction, which makes the concrete pile foundation subject to some physical pressure, resulting in cracking. The chemical corrosion is due to the reaction between the relevant components of cement and sulfate; the product has a certain expansibility, which also makes the concrete crack and damages the pile foundation. There are many studies on the diffusion reaction model of the sulfate and pile foundation, but because the mechanism of sulfate corrosion on the concrete pile foundation is very complex, most of the corrosion models of sulfate on the concrete pile foundation are empirical models, which have a lack of theory. Therefore, the research on sulfate corrosion on the concrete pile foundation needs to be further deepened. The concrete pipe pile is a high-strength prestressed pipe pile with high bearing capacity, short construction period, and reliable pile quality. However, due to its relatively short application time, the durability of the PHC pipe pile has not been paid much attention. However, the PHC pipe pile will also be corroded in the surrounding areas of the ocean, which seriously affects its structural life. Compared with the ordinary concrete structure, the PHC pipe pile has a certain particularity. Because of its structural characteristics, it bears the chemical and physical erosion on both sides at the same time [12].

At present, the research on the influence of chloride ion and sulfate ion on the durability of the concrete pile foundation is very rich and there are many practical research results. However, because the existing environment of the concrete pile foundation is very complex and there are many related factors, there are still many deficiencies and problems in the research on the durability of the concrete pile foundation. The following are the related problems in the durability research of the concrete pile foundation.

(1) In the corrosive environment, the durability of the concrete pile foundation is not controlled by a single factor, but by many physical and chemical reactionrelated factors. Its corrosion process is a complex and long process with certain particularity, so it needs to be studied systematically, However, most of the researches at home and abroad only focus on one or several factors, which makes the research results very scattered, and there is still a certain distance for the application of the durability design of the concrete pile foundation [13]

(2) From the current research point of view, many durability tests of the concrete pile foundation are conducted by improving the mass fraction of chloride ion and electrochemical methods to shorten the corrosion cycle, so as to obtain the relevant laws. 
However, this way will change the mechanism of the pile foundation corrosion process and the test results are different from the actual situation, so the reflection of the relevant laws is not true

(3) In the concrete pile foundation embedded in soil, there are some differences between the ion diffusion law of the pile soil interface and the ion diffusion law of the soaking corrosive agent in the test process. Moreover, the actual deformation and cracking process of the pile foundation will be constrained by soil, which is also different from that of soaking in solution. However, the current research on the mutual application of pile soil is relatively less. The mechanism is not clear [14]

(4) There are few studies on the relationship between the mechanical strength of the pile foundation and the damage of the concrete microstructure. Although there are some studies using a scanning electron microscope and X-ray diffraction to qualitatively analyze the damage of the concrete microstructure, there are few quantitative analyses. There is no correlation between the macrofracture and microdamage of the concrete pile foundation

Based on the pile foundation project of the Coastal Industrial Park, the site is located in a typical coastal environment and the content of chloride ion and sulfate ion in groundwater is more than $3000 \mathrm{mg} / \mathrm{L}$, far exceeding the maximum concentration limit of corrosive medium in the current national norms and industry standards, so the concrete structure has a high risk of corrosion damage. Through the preparation of different proportions of concrete, the effects of the water-cement ratio, cementitious materials, mineral powder, fly ash, preservatives, rust inhibitor, common- and high-efficiency preservatives on the mechanical properties, chloride ion permeability resistance, and sulfate resistance of marine pile foundation concrete are discussed and the optimal mix proportion of pile foundation corrosion-resistant concrete suitable for the project is proposed. It lays a foundation for the durability design of castin-place piles in corrosive sites, and the research results can also provide reference for the design of pile foundation engineering in similar sites.

\section{Theoretical Calculation Model}

2.1. Fick's Second Law. The life prediction theory of offshore structures is based on the two-stage life model of reinforced concrete structures proposed by Tuutti in 1982 [15]. In this model, the service life of the reinforced concrete structure is divided into two stages: the first stage is the chloride ion penetration stage (from the reinforced concrete entering seawater to the beginning of steel corrosion), in which the chloride ion concentration on the surface of steel reaches the concentration standard of its corrosion, and the second stage is from steel bar corrosion to the concrete expansion crack. In this stage, the corrosion products of the steel bar accumu- late and expand, resulting in concrete cracking, and the structural strength is reduced below the use requirements.

In order to accurately describe the chloride concentration in concrete, a lot of experiments have been done and many theories and models have been put forward. Based on Fick's second law, Collepardi et al. [16] established the chloride intrusion model as shown in equation (1) as follows:

$$
\rho_{\mathrm{cl}^{-}}(\mathrm{x} . t)=\rho_{\mathrm{cl}^{-}}, \mathrm{s}\left[1-\operatorname{erf}\left(\frac{x}{2 \sqrt{D_{0} \mathrm{t}}}\right)\right]
$$

where $\rho_{\mathrm{cl}^{-}}$(x.t) is the mass concentration of chloride ion at depth $x$ at time $t, \rho_{\mathrm{cl}^{-}}, \mathrm{s}$ is the mass concentration of external chloride ion, erf is the error function, and $D_{0}$ is the diffusion coefficient at the reference time.

In order to get more accurate results of structural life prediction, scholars have been modifying the relevant parameters according to the environmental conditions and material properties and using the modified model to predict the service life of concrete or the initial rust time of steel bars. In 1995, 12 countries, including Sweden, Germany, Norway, and the United Kingdom, jointly established the Dura Crete project [17]. According to the needs of the project, the factors affecting the service life of concrete, such as concrete age, initial curing time, environmental conditions, and test methods, were considered, the chloride ion diffusion invasion equation was modified, and the life prediction model was established. Due to the different depth of sea water and the distance from the coast, the durability life of marine structures is also different. Shi [18] conducted relevant erosion experiments according to different coastal environments and obtained time-varying models of chloride ion diffusion in concrete under different environmental conditions.

The diffusion process of chloride ion in concrete is influenced by many factors. The coupling effect of many factors should be considered when studying the diffusion process. Qi [19] studied the damage process under the coupling effect of the dry-wet cycle load salt solution, considered the influence of material-related factors (chloride ion binding capacity, chloride ion concentration in concrete, etc.) and environmental factors (load effect, environmental ion concentration, etc.), and proposed the chloride ion diffusion model of concrete under the coupling effect of load and chloride ion binding capacity.

2.2. Chloride Diffusion Model Based on Coupling of Environmental and Material Parameters. In saturated concrete, the main reason of chloride penetration is diffusion. In equation (1), it can be seen that the factors influencing chloride ion erosion include depth, time, chloride ion diffusion coefficient, and chloride ion concentration in concrete itself. In the early point of view, the diffusion coefficient $D$ is considered to be constant but it is actually a constantly changing value. For the convenience of practical engineering analysis, the diffusion coefficient $D$ selected in this paper is based on the benchmark diffusion coefficient, considering the influence of time and temperature. The corresponding 
calculation method of equivalent diffusion coefficient $D$ is shown in equations (2)-(4).

$$
\begin{gathered}
D=D_{0}(T) f\left(m, K_{m}\right), \\
y_{0}=y_{k} f(T)=\frac{T}{T_{0}} e^{q\left(\left(1 / T_{0}\right)-(1 / T)\right)}, \\
f(\mathrm{~m}, \boldsymbol{K m})=\frac{\mathrm{t}_{0}{ }^{K} m^{m} t-K_{m} m}{1-K_{m} m},
\end{gathered}
$$

where $T$ is the calculated temperature (absolute temperature), $T_{0}$ is the temperature at the reference diffusion coefficient $D_{0}, t_{0}$ is the recording time corresponding to $D_{0}, K_{m}$ is the influence factor of the material on the chloride diffusion coefficient, which is determined according to concrete type and experimental environment, $q$ is the activation constant, and $m$ is the time attenuation coefficient related to many factors.

The actual environment is different from the experiment. According to the indoor and outdoor experiments of Zhang and $\mathrm{Yu}$ [20], the ion diffusion equation is modified based on the relevant indoor and outdoor parameters. For this reason, the modified model considering the environmental and material factors is shown in equation (5) as follows:

$$
\begin{aligned}
\rho_{\mathrm{cl}^{-}}(x, t)= & K_{c} \bullet \rho_{\mathrm{cl}^{-}, 0}+\left(\rho_{\mathrm{cl}^{-}, s}-K_{c} \bullet \rho_{\mathrm{c}^{-}, 0}\right) \\
& \bullet\left[1-\operatorname{erf}\left(\frac{x}{2 \sqrt{D_{0} t_{0}{ }^{\prime} m^{m} t^{1-K m m} T \bullet e^{q\left(\left(1 / T_{0}\right)-(1 / T)\right)} /\left(1-K_{\mathrm{m}} \mathrm{m}\right) T_{0}}}\right)\right],
\end{aligned}
$$

where $x$ is the diffusion depth, $t$ is the diffusion time, $\rho_{\mathrm{cl}^{-}, 0}$ is the initial chloride concentration, and $K_{c}$ is the influence factor of curing conditions on the chloride diffusion coefficient.

\section{Test Overview}

3.1. Project Overview. The test site is located near the sea and belongs to the typical coastal shoal landform. Within a certain depth, the soil layers are dredged silt, muddy soil, and sandy soil in turn. The groundwater level of the proposed site is $0.6-1.2 \mathrm{M}$, the water level changes with the fluctuation of the sea tide, and the maximum variation range is about 3.0 M. The foundation form is a reinforced concrete castin-place pile, the bearing stratum at the pile end is argillaceous siltstone, the pile length is between $22 \mathrm{~m}$ and $23 \mathrm{~m}$, the pile diameter is $0.8 \mathrm{~m}$, and the concrete strength of the pile body is C50. The thickness of backfill soil is $10-15 \mathrm{~m}$, and the backfill material is mainly large-diameter broken stone, with the maximum particle size of about $2.0 \mathrm{M}$. The broken stone with a particle size more than $20 \mathrm{~cm}$ accounts for about $50 \%$ of the backfill material.

In order to study the soil corrosion of the project, soil samples were taken at the depth of $0.5,0.6$, and $0.6 \mathrm{~m}$ from the surface of four measuring points before backfill and buildings 5, 1, and 4 after backfill and the contents of
$\mathrm{Mg}^{2+}, \mathrm{SO}_{4}{ }^{2-}$, and $\mathrm{Cl}^{-}$and the $\mathrm{pH}$ value were measured. The soil corrosion before and after backfill is shown in Table 1 [21-24].

In order to study the groundwater corrosion of the site, samples were taken from three measuring points on the surface before backfilling and 3.7, 4.8, and $2.9 \mathrm{~m}$ below the surface of no. 5 , no. 1 , and no. 4 buildings, respectively, after backfilling. The contents of $\mathrm{Mg}^{2+}, \mathrm{SO}_{4}^{2-}$, and $\mathrm{Cl}^{-}$and the $\mathrm{pH}$ value of groundwater were measured. The groundwater corrosion before and after backfilling is shown in Table 2 .

It can be seen in Tables 1 and 2 that the dredger fill above the groundwater level before the site backfill belongs to super saline soil and that chloride ion and sulfate ion have strong corrosiveness to the structure and reinforcement. The deep backfill above the groundwater level before backfill and the site soil after backfill are all nonsaline soil, and the soil is slightly corrosive to the reinforced concrete structure. The proposed site before and after backfilling has strong corrosion to the reinforced concrete structure under the condition of alternate action of dry and wet groundwater and longterm immersion.

\subsection{Concrete Raw Materials}

3.2.1. Cement. p.II 52.5 Portland cement is used, the specific surface area of cement is greater than $300 \mathrm{~m}^{2} / \mathrm{kg}$ and less than $400 \mathrm{~m}^{2} / \mathrm{kg}$, and the volume stability is qualified.

3.2.2. Fly Ash: Class F, Grade H, $45 \mu$. The residue of $m$ square hole sieve is not more than $12 \%$, and the $\mathrm{CaO}$ content is less than $10 \%$.

3.2.3. Mineral Powder. S95 mineral powder with a specific surface area of more than $350 \mathrm{~m}^{2} / \mathrm{kg}$ and less than $450 \mathrm{~m}^{2} / \mathrm{kg}$ is used.

3.2.4. Sand. The sand is medium sand in zone II with a fineness modulus of $2.6-3.0$, with mud content of $2 \%$, and mud lump content of $0.5 \%$.

3.2.5. Gravel. The gravel has an acicular particle content of $7 \%$, clay content of $0.25 \%$, and mud content of $1 \%$.

3.2.6. Admixtures. The PCA-I polycarboxylate superplasticizer is used, the water reducing rate is $28 \%$, and the bleeding rate is less than 60\%; SBT-ZX (II) is used as a corrosion inhibitor for reinforced concrete. Ordinary and SBT-RMA (II) concrete preservatives are used as preservatives. The content of $\mathrm{MgO}$ is $2 \%$, the corrosion resistance coefficient is 0.95 , and the expansion coefficient is 1.2.

\subsubsection{Water. The water is ordinary tap water.}

3.3. Concrete Mix Proportion. According to the technical requirements of [25-27], the theoretical mix proportion index of cast-in-place pile concrete is proposed, as shown in Table 3. Based on the theoretical mix proportion of the cast-in-place pile, in order to study the influence of different concrete raw material ratios on the durability of the pile foundation, 7 groups of concrete samples were prepared according to different water-cement ratios, rubber material 
TABLE 1: Soil corrosion before and after backfilling.

\begin{tabular}{|c|c|c|c|c|c|c|c|}
\hline Time & Sampling location & Depth (m) & $\mathrm{Cl}^{-}\left(\mathrm{mg} \cdot \mathrm{kg}^{-1}\right)$ & $\mathrm{Mg}^{2-}\left(\mathrm{mg} \cdot \mathrm{kg}^{-1}\right)$ & $\mathrm{SO}_{4}{ }^{2-}\left(\mathrm{mg} \cdot \mathrm{kg}^{-1}\right)$ & $\mathrm{PH}$ & Corrosion \\
\hline \multirow{4}{*}{ Before backfilling } & S1 & 0 & 48031.51 & 4341.17 & 47161.62 & 7.59 & Strong \\
\hline & S2 & 0 & 49123.15 & 4031.09 & 9643.86 & 7.42 & Strong \\
\hline & S3 & 0 & 88.44 & 22.35 & 158.85 & 7.33 & Micro \\
\hline & S4 & 0 & 125.07 & 24.84 & 213.49 & 7.35 & Micro \\
\hline \multirow{3}{*}{ After backfilling } & $5 \#$ & 0.5 & 74.55 & 40.37 & 194.88 & 7.42 & Micro \\
\hline & $1 \#$ & 0.6 & 60.72 & 39.39 & 191.03 & 7.59 & Micro \\
\hline & $4 \#$ & 0.6 & 75.98 & 37.60 & 252.49 & 7.60 & Micro \\
\hline
\end{tabular}

TABLE 2: Groundwater corrosion before and after backfilling.

\begin{tabular}{lccccccc}
\hline Time & Sampling location & Depth $(\mathrm{m})$ & $\mathrm{Cl}^{-}\left(\mathrm{mg} \cdot \mathrm{kg}^{-1}\right)$ & $\mathrm{Mg}^{2-}\left(\mathrm{mg} \cdot \mathrm{kg}^{-1}\right)$ & $\mathrm{SO}_{4}{ }^{2-}\left(\mathrm{mg}^{2} \mathrm{~kg}^{-1}\right)$ & $\mathrm{PH}$ & $\mathrm{Corrosion}^{-}$ \\
\hline \multirow{3}{*}{ Before backfilling } & S5 & 0 & 43863.54 & 2266.99 & 4298.69 & 8.48 & Strong \\
& S6 & 0 & 43897.13 & 2272.95 & 4346.77 & 8.54 & Strong \\
& S7 & 0 & 43874.72 & 2269.33 & 4308.24 & 8.50 & Strong \\
After backfilling & 5\# & 3.7 & 34739.81 & 1739.67 & 4110.91 & 8.51 & Strong \\
& $1 \#$ & 4.8 & 41101.75 & 1551.85 & 3821.08 & 8.37 & Strong \\
& 4\# & 2.9 & 36738.28 & 1724.10 & 4123.06 & 8.45 & Strong \\
\hline
\end{tabular}

TABle 3: Mix proportion design index of the cast-in-place concrete pile.

\begin{tabular}{|c|c|c|c|c|c|c|c|c|c|}
\hline $\begin{array}{l}\text { Strength } \\
\text { grade }\end{array}$ & $\begin{array}{l}\text { Slump } \\
(\mathrm{m})\end{array}$ & $\begin{array}{c}\text { Air } \\
\text { content } \\
(\%)\end{array}$ & $\begin{array}{l}\text { Water- } \\
\text { cement } \\
\text { ratio }\end{array}$ & $\begin{array}{l}\text { Fly ash } \\
\text { content } \\
(\%)\end{array}$ & $\begin{array}{c}\text { Mineral } \\
\text { powder } \\
\text { content }(\%)\end{array}$ & $\begin{array}{l}\text { Amount of } \\
\text { rubber } \\
\text { material }(\%)\end{array}$ & Admixture & $\begin{array}{l}28 \mathrm{~d} \text { chloride } \\
\text { diffusion } \\
\text { system }\left(\mathrm{m}^{2} / \mathrm{s}\right)\end{array}$ & $\begin{array}{l}\text { Corrosion resistance } \\
\text { coefficient of } \\
\text { compressive strength }\end{array}$ \\
\hline C50 & $200 \sim 220$ & $3.0 \sim 3.6$ & $0.32 \sim 0.34$ & $15 \sim 20$ & $30 \sim 40$ & $\geq 360$ & $\begin{array}{c}\text { Preservative } \\
\text { and rust } \\
\text { inhibitor }\end{array}$ & $\leq 6 \times 10-12$ & $\geq 0.90$ \\
\hline
\end{tabular}

dosage, fly ash dosage, and mineral powder dosage, as well as whether to add admixture, ordinary admixture, and highefficiency admixture. The mix proportion and admixture proportion of C50 concrete are shown in Table 4.

\section{Test Method}

Chloride diffusion coefficient and sulfate corrosion resistance grade of cast-in-place pile concrete are two main indexes to evaluate its durability. The compressive strength of 7 groups of samples was tested at $7 \mathrm{~d}$ and $28 \mathrm{~d}$, to analyze their mechanical properties. The nonsteady state rapid chloride migration (RCM) method was used to test the resistance of concrete to chloride ion penetration for 28 days, and the chloride ion diffusion coefficient was calculated. On this basis, accelerated tests with different evaluation periods are carried out to test the sulfate resistance of concrete and the compressive corrosion coefficient and mass loss rate are calculated.

4.1. Evaluation of Chloride Resistance. In this test, 7 groups of pile foundation concrete samples with different mix proportions were prepared and the size was $100 \mathrm{~mm} \times 100 \mathrm{~mm}$ . The standard method was used for curing for 28 days, and the resistance to chloride ion erosion was evaluated according to $[28,29]$.
4.2. Evaluation of Sulfate Resistance. According to the technical requirements of [30], it takes 176 days to evaluate the sulfate corrosion resistance of concrete. Considering the urgency of the construction period, the indoor accelerated test method is used to simulate the sulfate corrosion environment. The compressive strength (corrosion resistance coefficient) and weight loss rate of the specimen are tested after 10, 20, and 30 cycles in each cycle, and the accelerated test scheme of pile foundation concrete suitable for the service environment of the project is proposed, as shown in Table 5.

\section{Analysis of Test Results}

5.1. Analysis of Mechanical Properties of Concrete. The histogram of compressive strength of concrete samples at different ages shows that the influence of concrete raw materials with different mix proportions on the concrete structure is different. The compressive strength of concrete samples with 7 mix proportions at 14 and 28 days is shown in Figure 1.

It can be seen in Figure 1 that the $28 \mathrm{~d}$ compressive strength of seven groups of concrete samples has increased by $29.0 \%, 42.0 \%, 39.6 \%, 50.0 \%, 34.7 \%, 52.2 \%$, and $50.0 \%$ compared with that of $14 \mathrm{~d}$. The $28 \mathrm{~d}$ compressive strength of the E6 group is the highest; the highest is $65.4 \mathrm{MPa}$, which is $26 \mathrm{MPa}$ higher than the $14 \mathrm{~d}$ compressive strength. The 
TABLE 4: Concrete mix proportion and specific gravity of admixture.

\begin{tabular}{|c|c|c|c|c|c|c|c|c|c|c|c|}
\hline Number & $\begin{array}{l}\text { Water- } \\
\text { cement } \\
\text { ratio }\end{array}$ & $\begin{array}{l}\text { Amount of } \\
\text { rubber } \\
\text { material } \\
\left(\mathrm{kg} \cdot \mathrm{m}^{-3}\right)\end{array}$ & $\begin{array}{l}\text { Cement } \\
\left(\mathrm{kg} \cdot \mathrm{m}^{-3}\right)\end{array}$ & $\begin{array}{c}\text { Sand } \\
\left(\mathrm{kg} \cdot \mathrm{m}^{-3}\right)\end{array}$ & $\begin{array}{l}\text { Crushed } \\
\text { stone } \\
\left(\mathrm{kg} \cdot \mathrm{m}^{-3}\right)\end{array}$ & $\begin{array}{l}\text { Fly } \\
\text { ash } \\
(\%)\end{array}$ & $\begin{array}{l}\text { Mineral } \\
\text { powder } \\
(\%)\end{array}$ & $\begin{array}{c}\text { General } \\
\text { preservatives } \\
(\%)\end{array}$ & $\begin{array}{c}\text { Efficient } \\
\text { preservative } \\
(\%)\end{array}$ & $\begin{array}{l}\text { Common } \\
\text { rust } \\
\text { inhibitor } \\
(\%)\end{array}$ & $\begin{array}{l}\text { High- } \\
\text { efficiency } \\
\text { rust } \\
\text { inhibitor } \\
(\%)\end{array}$ \\
\hline E1 & 0.34 & 450 & 225 & 767 & 1016 & 20 & 30 & 0 & 0 & 0 & 0 \\
\hline E2 & 0.36 & 450 & 225 & 764 & 1010 & 20 & 30 & 0 & 0 & 0 & 0 \\
\hline E3 & 0.34 & 450 & 225 & 767 & 1016 & 16 & 24 & 10 & 0 & 2 & 0 \\
\hline $\mathrm{E} 4$ & 0.34 & 450 & 225 & 767 & 1016 & 16 & 24 & 0 & 10 & 2 & 2 \\
\hline E5 & 0.32 & 480 & 192 & 755 & 1001 & 20 & 40 & 0 & 0 & 0 & 0 \\
\hline E6 & 0.32 & 480 & 192 & 755 & 1001 & 15 & 35 & 10 & 0 & 2 & 0 \\
\hline E7 & 0.32 & 480 & 192 & 755 & 1001 & 15 & 35 & 0 & 10 & 0 & 2 \\
\hline
\end{tabular}

TABLe 5: Accelerated test system of pile foundation concrete.

\begin{tabular}{|c|c|c|c|c|c|c|c|}
\hline $\begin{array}{l}\text { Evaluation } \\
\text { cycle (d) }\end{array}$ & $\begin{array}{l}\text { Curing } \\
\text { time } \\
\text { (d) }\end{array}$ & $\begin{array}{l}\text { Corrosion } \\
\text { days }(\mathrm{d})\end{array}$ & $\begin{array}{l}\text { Soaking } \\
\text { solution }\end{array}$ & $\begin{array}{c}\text { Mechanism } \\
\text { of dry-wet } \\
\text { cycle }\end{array}$ & $\begin{array}{c}\text { Drying } \\
\text { temperature } \\
\left({ }^{\circ} \mathrm{C}\right)\end{array}$ & $\begin{array}{c}\text { Soaking } \\
\text { temperature } \\
\left({ }^{\circ} \mathrm{C}\right)\end{array}$ & Evaluating indicator \\
\hline 44 & 14 & 30 & $\begin{array}{c}10 \% \\
\mathrm{Na}_{2} \mathrm{SO}_{4}\end{array}$ & $\begin{array}{l}\text { Soak } 12 \mathrm{~h}, \\
\text { dry } 12 \mathrm{~h}\end{array}$ & 65 & 25 & \multirow{3}{*}{$\begin{array}{c}\text { The compressive strength (corrosion resistance } \\
\text { coefficient) and weight loss rate of specimens } \\
\text { were calculated after 10, 20, and } 30 \text { corrosion } \\
\text { cycles }\end{array}$} \\
\hline 88 & 28 & 60 & $\begin{array}{c}10 \% \\
\mathrm{Na}_{2} \mathrm{SO}_{4}\end{array}$ & $\begin{array}{l}\text { Soak } 12 \mathrm{~h} \text {, } \\
\text { dry } 12 \mathrm{~h}\end{array}$ & 40 & 15 & \\
\hline 176 & 56 & 120 & $\begin{array}{c}5 \% \\
\mathrm{Na}_{2} \mathrm{SO}_{4} \\
\end{array}$ & $\begin{array}{c}\text { Soak } 16 \mathrm{~h} \\
\text { Dry } 6 \mathrm{~h}\end{array}$ & 80 & 20 & \\
\hline
\end{tabular}

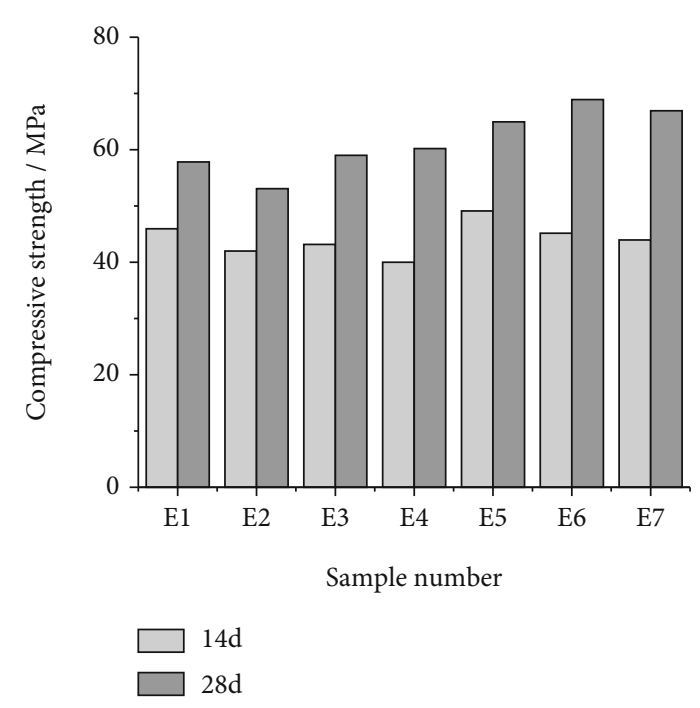

Figure 1: Compressive strength of pile foundation concrete.

$28 \mathrm{~d}$ compressive strength of the E2 group is the lowest; the lowest is $51.0 \mathrm{MPa}$. Compared with $\mathrm{E} 2$, the $28 \mathrm{~d}$ compressive strength of the E6 group increased by about $30 \%$. The compressive strength of E6 mixed with the ordinary corrosion inhibitor and preservative is $9.38 \%$ higher than that of E5 without, and that of E7 mixed with high-efficiency additive is $6.25 \%$ higher than that of E5 without. The reason may be that magnesium oxide in the ordinary corrosion inhibitor and preservative makes expansion to improve compactness and the pores and voids in concrete are filled by bubbles, which reduces water consumption. The compressive strength of concrete is improved. The difference of compressive strength between E6 and E7 at the age of 14 and 28 days is small, and the compressive strength of concrete at the age of 28 days is higher than that of other groups, which indicates that the admixtures can promote the growth of concrete strength at the later stage. Compared with the sample $\mathrm{E} 2$, the water-cement ratio of E1 is smaller and the compressive strength of concrete is higher, which indicates that the water-cement ratio is one of the main factors affecting the strength of concrete. When the water-cement ratio is reduced by 0.02 , the compressive strength of concrete is increased by $5 \%$. This is because reducing the watercement ratio properly can reduce the connected pores formed by the excess water of cement hydration during the solidification process, to achieve the purpose of improving the strength of concrete.

Considering the economy and durability of the project, it is recommended to select $450 \mathrm{~kg} / \mathrm{m}^{3}$ glue material and the water-glue ratio should not be higher than 0.34 for the preparation of pile foundation concrete.

5.2. Chloride Penetration Resistance of Concrete. In view of the special environment of the project, in order to better verify the antichloride ion erosion performance of mineral powder, rubber material dosage, water-cement ratio, preservative, and rust inhibitor, seven groups of concrete samples with different mix proportions were tested for antichloride 
ion penetration at the age of 28 days to determine the chloride ion diffusion coefficient. The test results are shown in Figure 2 .

It can be seen in Figure 2 that the water-cement ratios of group E1 and group E2 with the same amount of adhesive material of $450 \mathrm{~kg} / \mathrm{m}^{3}$ and without preservative and rust inhibitor are larger and the chloride ion diffusion coefficient is the largest at 28 days, with the maximum of $5.1 \times 10-$ $12 \mathrm{~m}^{2} / \mathrm{s}$, which is because the higher the water-cement ratio is, the greater the porosity of the hardened concrete is, the less dense the concrete is, and the chloride ion invades into the concrete from the pores on the concrete surface. When the chloride ion concentration reaches $0.17 \%-2.5 \%$, the acid environment required for chemical reaction is met and the chloride ion is very easy to damage the passive film on the steel surface and cause steel corrosion. The volume of Fe $(\mathrm{OH}) 3 \cdot 10$ h2o produced by the hydration of iron rust $\left(\mathrm{Fe}_{2} \mathrm{O}_{3}\right)$ increases to 10 times of the original, which leads to the cracking of the reinforced concrete cover and seriously affects the durability of concrete. For E5, E6, and E7, the chloride diffusion coefficient of E5 mixed with $40 \%$ mineral powder is 3.5 at the same water-cement ratio and rubber dosage. The chloride diffusion coefficient of E6 mixed with common additive is 3.2. The chloride diffusion coefficient of E7 mixed with high-efficiency additive is 3.1. The results show that E7 $>$ E6 $>$ E5, which indicates that the highefficiency preservative and rust inhibitor have better resistance to chloride ion corrosion than the common type. The addition of mineral powder can improve the chloride ion permeability of concrete, which may be because slag can make the early strength and density of concrete increase rapidly, The more-dense concrete can prevent the invasion speed of chloride ion and reduce the damage to the concrete structure. The diffusion coefficient of chloride ion in $28 \mathrm{~d}$ of concrete samples with seven ratios is $\leq 6 \times 10-12 \mathrm{~m}^{2} / \mathrm{s}$, meeting the design requirements.

5.3. Sulfate Corrosion Resistance of Concrete. The compressive strength ratios (compressive corrosion resistance coefficient) of 7 concrete samples with different proportions were calculated after 10, 20, and 30 accelerated sulfate corrosion tests after $30-120$ days of corrosion in $10 \%, 10 \%$, and $5 \%$ $\mathrm{Na}_{2} \mathrm{SO}_{4}$ solution, as shown in Figure 3.

It can be seen in Figure 3 that the compressive corrosion coefficient of E1-E5 concrete samples after 10 times of accelerated sulfate corrosion cycles is obviously higher than those of 20 and 30 times of accelerated sulfate corrosion cycles, which indicates that sulfate and cement hydration products $\mathrm{Ca}(\mathrm{OH})_{2}$, calcium silicate hydrate $(\mathrm{C}-\mathrm{S}-\mathrm{H})$, and calcium silicate hydrate $(\mathrm{C}-\mathrm{S}-\mathrm{H})$ in concrete are closely related to each other. The hydrated calcium aluminate $(\mathrm{C}-\mathrm{A}-\mathrm{H})$ gel reacts to produce a large amount of three sulfur-type hydrated calcium sulphoaluminate and natural two water gypsum $\left(\mathrm{CaSO}_{4} .2 \mathrm{H}_{2} \mathrm{O}\right)$ crystal inside the concrete structure, making the early concrete structure more dense; the greater the compressive corrosion coefficient, and the better sulfate corrosion resistance in the early stage. After 30 times of the accelerated sulfate corrosion cycle, the compressive corrosion coefficient decreases sharply, which indicates that the

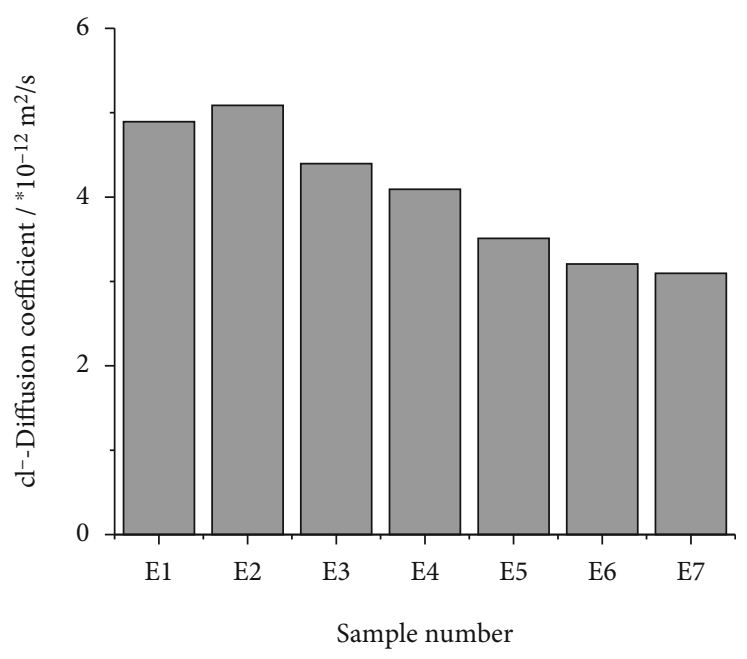

FIGURE 2: Chloride diffusion coefficient of pile foundation concrete in 28 days.

corrosion products with weak cementation ability will be formed and the water absorption expansion will damage the cement concrete structure and reduce the sulfate corrosion resistance. Among them, the water-cement ratio of group E2 is 0.36, the dosage of the glue material is $450 \mathrm{~kg} / \mathrm{m}^{3}$, and no preservatives and rust inhibitors are added. After 10 accelerated sulfate corrosion cycles, the compressive corrosion coefficient is the highest, about 1.25. After 30 sulfate dry-wet cycles, the compressive corrosion coefficient is the lowest; the lowest is 0.78 , far less than the design requirement of 0.9 . There are many pores and cracks in the concrete structure, $\mathrm{SO}_{4}{ }^{2-}$ is easy to invade into the concrete, and the sulfate corrosion rate is the fastest. After 10, 20, and 30 times of sulfate drying and wetting cycles, the compressive corrosion coefficients of E5 mixed with $40 \%$ mineral powder and $20 \%$ fly ash are $1.49,0.9$, and 0.88 , which indicates that the addition of mineral powder can enhance the sulfate corrosion resistance of concrete, which is almost close to the design requirements. The reason may be that the addition of mineral powder can effectively reduce the content of $\mathrm{C} 3 \mathrm{~A}$ in the adhesive and consume the excess hydration product $\mathrm{Ca}(\mathrm{OH})_{2}$. After 10, 20, and 30 times of the accelerated sulfate corrosion cycle test, the compressive corrosion coefficient of E6 was 1.0, 0.98, and 0.91 . It can be seen that the compressive corrosion coefficient did not decrease significantly and was greater than the design value of 0.9 , indicating that the general preservative can improve the compactness by introducing magnesium oxide to make expansion and prevent crystal expansion corrosion. The durability of concrete is obviously improved. E7 uses the same proportion of the efficient corrosion agent and rust inhibitor; after 10, 20, and 30 times of the accelerated sulfate corrosion cycle, the measured compressive corrosion coefficients of the concrete pile foundation are $1.0,0.98$, and 0.97 , respectively. It can be seen that the compressive corrosion coefficient is basically unchanged, and compared with other groups, it has a higher corrosion resistance coefficient and lower expansion coefficient. It is indicated that the addition of high-efficiency admixture 


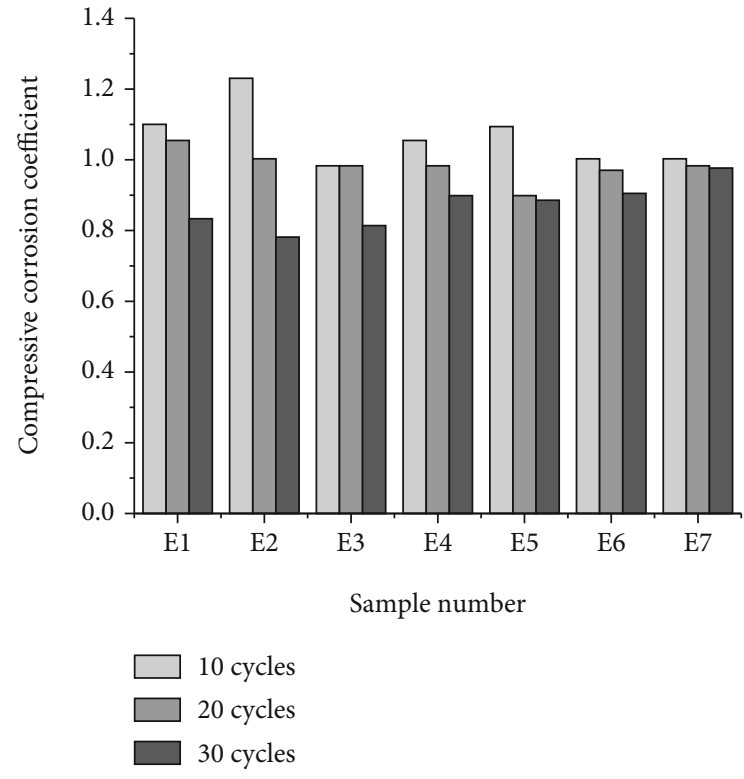

Figure 3: Accelerated sulfate corrosion 0 cyclic compressive corrosion coefficient of pile foundation concrete.

ensures that the pile foundation concrete can resist both the dilatation of crystal and the destruction of gel decomposition. From the point of view of compression and corrosion resistance coefficient, concrete should be prepared with the $480 \mathrm{~kg} / \mathrm{m}^{3}$ cementitious material, $15 \%$ fly ash, $35 \%$ mineral powder, and 0.34 water binder ratio. The test method of concrete should meet the design requirements of the ks 120 sulfate resistance grade. The mass loss rate of 7 groups of concrete samples after 10 and 30 accelerated sulfate corrosion cycles is shown in Figure 4.

It can be seen in Figure 4 that the compressive corrosion coefficients of E2, E4, and E6 samples after 10 accelerated sulfate corrosion cycles appear to be negative, which indicates that the quality of concrete has increased, especially when the water-cement ratio of E2 samples is the largest and no additives are added; the concrete quality increases by more than $15 \%$ after 10 accelerated sulfate corrosion cycles. The reason may be that the higher the watercement ratio is, the less dense the concrete structure is, and there are more pores. Sulfate ion invades into the concrete through the pores and microcracks on the concrete surface, forming insoluble calcium sulphoaluminate hydrate and $\mathrm{CaSO} 4 \cdot 2 \mathrm{H}_{2} \mathrm{O}$ crystals, which leads to the increase of the concrete quality. After 30 accelerated sulfate corrosion cycles, the quality losses of E1 and E2 concrete are very serious. The reason is that sulfate reacts with cement hydration products in concrete to form ettringite and gypsum which can degrade concrete. The internal stress caused by volume expansion leads to cracking and erosion of concrete. At the same time, sulfate reacts with cement hydration products to destroy the chemical balance of the system, resulting in the dissolution and decomposition of hydrate. The mass loss rate of E7 concrete mixed with the high-efficiency preservative and rust inhibitor is $101 \%$ lower than that of E1 concrete after 30 times of accelerated sulfate corrosion cycles. In the

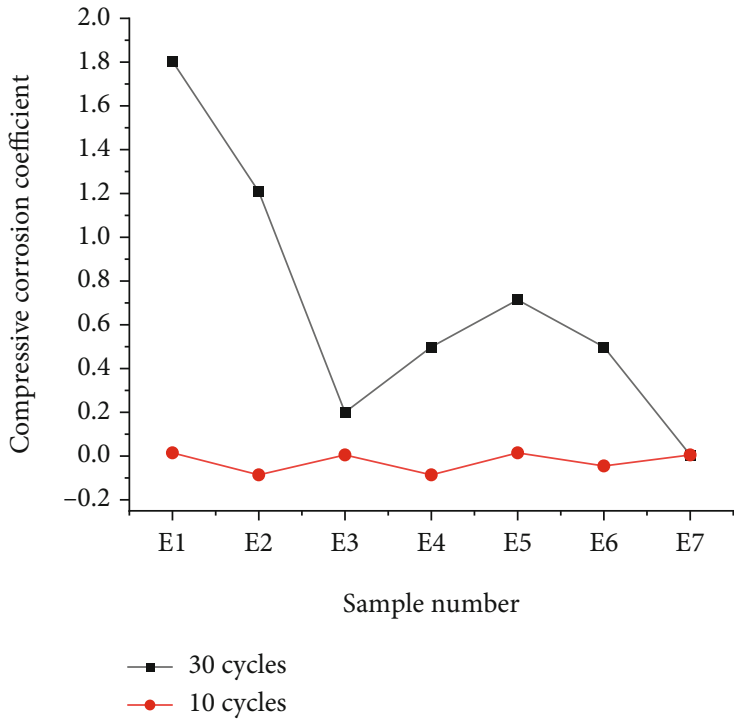

FIGURE 4: Mass loss rate of the accelerated sulfate corrosion cycle of pile foundation concrete.

whole cycle, the mass of E7 concrete is almost unchanged, which indicates that the density of concrete does not change, the structure is not damaged, and the durability of concrete is guaranteed after many times of sulfate corrosion cycles of E7 concrete mixed with the high-efficiency preservative and rust inhibitor.

\section{Conclusion}

(1) The E6 sample has the highest compressive strength $(65.4 \mathrm{MPa})$. The diffusion coefficient of chloride ion in 28 days of 7 groups of samples is less than $6 \times$ $10^{-12} \mathrm{~m}^{2} / \mathrm{s}$, meeting the design requirements. The compressive corrosion coefficient of sample E7 is basically unchanged due to the addition of the high-efficiency preservative and rust inhibitor, and the quality of sample E7 hardly changes during the whole accelerated sulfate corrosion cycle

(2) Under the test conditions, the theoretical mix proportion of pile foundation corrosion-resistant concrete suitable for the project is proposed: the amount of glue material $\geq 360 \mathrm{~kg} / \mathrm{m}^{3}$, water-cement ratio $0.32 \sim 0.34$, fly ash $15 \% \sim 20 \%$, mineral powder $30 \% \sim 40 \%$, sand rate $38 \% \sim 43 \%$, adding preservatives, rust inhibitor, and other additives

(3) The water-cement ratio is one of the main factors that affect the compressive strength of concrete. The addition of mineral powder can significantly enhance the chloride resistance of concrete. An appropriate amount of fly ash can enhance the antisulfuric acid corrosion ability of the concrete cementitious system. In general, the high-efficiency preservatives and rust inhibitors are better than the common ones 
(4) Based on the theoretical mix proportion of concrete, the amount of various raw materials to meet the durability requirements of the project is put forward: $480 \mathrm{~kg} / \mathrm{m}^{3}$ of glue, 0.34 of the water-cement ratio, $15 \%$ of fly ash, $40 \%$ of mineral powder, $10 \%$ of efficient preservative, and $2 \%$ of efficient rust inhibitor

\section{Data Availability}

The data used to support the findings of this study are included with the article.

\section{Conflicts of Interest}

The author declare that there is no conflict of interest regarding the publication of this paper.

\section{Acknowledgments}

The study is supported by the project of the Science and Technology Bureau of Hengyang City (PN:2019jhzx1173): study on the load-bearing capacity of connecting joints of self-stabilizing shear wall structures and the science and technology planning project of the Education Department of Hunan Province (PN:19C0526): study on the loadbearing capacity of connecting joints of self-stabilizing shear wall structures.

\section{References}

[1] C. Liu, X. Hu, R. Yao et al., "Assessment of soil thermal conductivity based on BPNN optimized by genetic algorithm," Advances in Civil Engineering, vol. 2020, Article ID 6631666, 10 pages, 2020.

[2] J. Du, G. Zheng, B. Liu, N.-J. Jiang, and J. Hu, "Triaxial behavior of cement-stabilized organic matter-disseminated sand," Acta Geotechnica, vol. 16, no. 1, pp. 211-220, 2021.

[3] X. Shi, N. Xie, K. Fortune, and J. Gong, "Durability of steel reinforced concrete in chloride environments: an overview," Constructionand Building Materials, vol. 30, no. 5, pp. 125138, 2012.

[4] J. Ding, F. Ning, and Q. Wang, "Corrosion research on pile concrete in saline groundwater environments," Concrete, vol. 6, pp. 153-156, 2015.

[5] S. H. Han, "Influence of diffusion coefficient on chloride ion penetration of concrete structure," Construction and Building Materials, vol. 21, no. 2, pp. 370-378, 2007.

[6] D. Zhang, B. Liu, and T. J. Xu, "Test research on sulfate- corrosion resistance abilityinfluence of anti- corrosion agent to concrete," Concrete, vol. 40, pp. 95-97, 2013.

[7] C. Y. X. Y. D. Qingjun and L. Yunlong, "Study on the Corrosive Mechanism of Reinforced Concrete in Acid Mediums," Journal of Wuhan University of Technology, vol. 23, no. 8, pp. 4-6, 2001.

[8] Y. Ge, J. Yuan, W. C. Yang, G. P. Zhang, and B. S. Zhang, "Property of Fly-ash Concrete in Sodium Sulfate Solution Under Freeze-thaw and Dry-wet Cycling," Journal of Wuhan University of Technology, vol. 30, no. 6, pp. 33-36, 2008.

[9] C. Y. Liu, Y. Wang, X. M. Hu, Y. L. Han, X. P. Zhang, and L. Z. $\mathrm{Du}$, "Application of GA-BP neural network optimized by Grey
Verhulst model around settlement prediction of foundation pit," Geofluids, vol. 2021, Article ID 5595277, 16 pages, 2021.

[10] M. M. Rahman and M. T. Bassuoni, "Thaumasite sulfate attack on concrete: mechanisms, influential factors and mitigation," Construction and Building Materials, vol. 73, pp. 652-662, 2014.

[11] C. A. Apostolopoulos, S. Demis, and V. G. Papadakis, "Chloride-induced corrosion ofsteel reinforcement-Mechanical performance and pit depth analysis," Construction and BuildingMaterials, vol. 38, no. 2, pp. 139-146, 2013.

[12] A. R. Suleiman, A. M. Soliman, and M. L. Nehdi, "Effect of surface treatment on durability of concrete exposed to physical sulfate attack," Construction and Building Materials, vol. 73, pp. 674-681, 2014.

[13] L. Jiang, D. Niu, L. Yuan, and Q. Fei, "Durability of concrete under sulfate attack exposed to freeze-thaw cycles," Cold Regions Science and Technology, vol. 112, pp. 112-117, 2015.

[14] N. Jin, Y. Xu, C. Fu, X. Jin, and Z. Wang, "Influence ofcarbonation, chloride attack and loading on concrete deterioration," Journal of the Chinese Ceramic Society, vol. 43, no. 10, pp. 1483-1491, 2015.

[15] K. Tuutti, Corrosion of Steel in Conerete, vol. 91, no. 4, 1982, Swedish Cenent and Concrete Research Institute, Stockholm, 1982.

[16] M. Collepardi, A. Marcialis, and R. Turriziani, "The kinetics of chloride ions penetration in concrete," II Cementoz, vol. 4, pp. 157-164, 1970.

[17] S. Engelund, C. Edvardsen, and L. Mohr, General guidelines for durability design and redesign. Report R15 of EU-Brite EuRam III project BE95-1347 DuraCrete, Probabilistic performance based durability design of concrete structures, 2000.

[18] J. Shi, Test and Similarity of Chloride Resistance of Cement Based Materials under Different Dry Wet Cycles, Zhejiang University of Technology, Hangzhou, 2015.

[19] B. Qi, Study on Corrosion Resistance and Mechanism of Recycled Concrete under Multi Factor Coupling, Nanjing: Southeast University, 2017.

[20] L. Zhang and H. Yu, "Research on chloride diffusion of concrete based on indoor and outdoor correlation method," Zhejiang Construction, vol. 35, no. 2, pp. 46-49, 2018.

[21] D. Chen and S. Mahadevan, "Chloride-induced reinforcement corrosion and concrete cracking simulation," Cement and Concrete Composites, vol. 30, no. 3, pp. 227-238, 2008.

[22] A. Boddy, E. Bentz, M. D. A. Thomas, and R. D. Hooton, “An overview and sensitivity study of a multimechanistic chloride transport model," Cement and Concrete Research, vol. 29, no. 6, pp. 827-837, 1999.

[23] M. Collepardi, A. Marcialis, and R. Turriziani, "Penetration of chloride ions into cement pastes and concretes," Journal of theAmerican Ceramic Society, vol. 55, no. 10, pp. 534-535, 1972.

[24] S. H. Lin, "Chloride diffusion in porous concrete under conditions of variable temperature," Wärme- und Stoffübertragung, vol. 28, no. 7, pp. 411-415, 1993.

[25] K. Bhargava, A. K. Ghosh, Y. Mori, and S. Ramanujam, "Modeling of time to corrosion-induced cover cracking in reinforced concrete structures," Cement and Concrete Research, vol. 35, no. 11, pp. 2203-2218, 2005.

[26] K. Bhargava, A. K. Ghosh, Y. Mori, and S. Ramanujam, "Model for cover cracking due to rebar corrosion in RC 
structures," Engineering Structures, vol. 28, no. 8, pp. 10931109, 2006.

[27] Y. Liu and R. E. Weyers, "Modeling the time to corrosion cracking in chloride contaminated reinforced concrete structures," ACI Materials Journal, vol. 95, no. 6, pp. 675-681, 1998.

[28] E. Samson, J. Marchand, and J. J. Beaudoin, "Modeling the influence of chemical reactions on the mechanisms of ionic transport in porous materials: an overview," Cement and Concrete Research, vol. 30, no. 12, pp. 1895-1902, 2000.

[29] X. B. Zuo and W. Sun, "Full process analysis of damage and failureof concrete subjected to external sulfate attack," Journal of the Chinese Ceramic Society, vol. 37, no. 7, pp. 1063-1067, 2009.

[30] B. Yu, L. F. Yang, M. Wu, and B. Li, "Practical model for predicting corrosion rate of steel reinforcement in concrete structures," Construction and Building Materials, vol. 54, pp. 385401, 2014. 